\title{
THE NON-PAY SYSTEM
}

TIIERE is a point in the discussion of the non-pay system which those arguing in its faror seem to lose sight of in comparing the education of a nurse with that of any other profession, and that is in the amount of hard manual labor which most of the schools require the nurse to perform for the hospital.

In the great majority of training-schools nurses are working in the wards from ten to twelve hours per day; lectures and classes are more a matter of accident than of regular rontine, and such instruction, when given at all, is taken from the time which should properly be spent by the nurse in rest, recreation, or sleep.

While these conditions prevail so largely, it secms hardly fair to compare the methods of the education of the nurse with those of any other profession.

In a school giving eight hours of praetieal work in the wards, with a carefully systematized eourse of theoretieal instruetion, the non-pay plan seems perfectly just; but we should bear in mind that even to-day, with all of our boasted progress, there are great numbers of hospitals where the training-school exists beeause it is the eheapest serviee the hospital ean obtain, and systematie instruction is not regarded as an essential part of the obligation due the pupil. The universal adoption of the non-pay system opens the way for still greater injustiee on the part of sueh schools, and we think the endorsement by the profession of a general plan of this kind should be given carefully. A few hospitals, with the Johns Hopkins leading, have introdueed the eight-hour plan, with no pay and an educational basis. Many will follow on these lines. It is unquestionably the ideal method of the future, but we do not hesitate to say that the vast majority of the training-schools to-day are not ready for it.

\section{NURSING INSTITUTES}

AlL of the faeilities for establishing a lursing institute are to be found in the Meehanies' Institute of Roehester, N. Y., and in the new teehnieal school for women, lately established in Boston, to be called Simmons College, it is proposed to have a department deroted to the preliminary training of nurses. The superintendents of the leading hospitals in both these cities are interesting themselves in the movement, and we shall give an account of the progress made in our next number.

TIIE programme of the annual meeting of the Trained Nur'ses' Associated Alummæ of the United States, to be held in Chieago, May 1, 2, 3, is given on another page, and is suggestive of a very interesting occasion. The president, Miss Annie Damer, of Buffalo, is an able execntive officer, and Chicago is not only an important nursing centre, but is one of the most attractive cities in the country to visit. We prediet a very good time to all who are able to be present.

\section{THE JOURNAL CONTLNTS}

IN the near future we shall give, in addition to the papers already announced, a series of articles on changes in methods of teaching in training-school work by Miss Nutting, of the Johns Fopkins; Dr. Richard Cabot, of the Massaehusetts General; Dr. Alfred Worcester, of Waltham, and Miss H. McNillan, of the Lakeside Hospital, Cleveland. These papers will be of especial value to 
worker's in these lines, but the suhject is one of interest to all of our readers, as slowing the trend of progress in the education of the nurse.

Two paper's on invalid life in the Adirondacks and in Colorado, written by nurses who are themselves under treatment for tuberculosis, will give a most practical side of the life in such resorts, showing also the cost of treatment, and giving just the kind of information that a nurse should have at her command as she goes about tlie world where people so frequently ask for advice in such matter's.

A paper (illustrated) on "Child Saving in Baltimore," by Miss Annie E. Rutherford, a Johns Hoplins graduate, who is working in that field; a series of papers on "Alumnx Periodicals," showing the influence of the local journals on the alumne association; a series of papers on "Hygiene of the Household," by Miss Eveleen Harrison, the first of which is given in the present number. Miss Harrison is a graduate of the Post-Graduate Hospital School of New York City, and has written a book on home nursing, of which mention has already been made in this JourNal.

Miss Linda Richards will give an account of her experiences in English hospitals in 1876-77.

Mrs. Ellen M. Richards, of the Institute of Technology, Boston, has promised a paper on the food question in large institutions.

Miss Dickinson, one of the lead sisters of the London Hospital, England, will contribute a paper on the "Finsen Light Trcatment."

Mrs. Alice P. Norton, of the University of Chicago, will later contribute a series of papers on interesting domestic science subjects.

The papers read by Mrs. Nutting and Miss Richards at the National Council of Women in Washington, recently, with the papers and reports from the Alumnæ meeting to be held in Chicago in May and from the Superintendents' meeting in Detroit in September.

Our pages will be well filled during the remaining half of the year, and as the subscription list grows steadily larger, we may safely say that our magazine has passed the experimental stage and stands as an assured success in the jomrnalistic world. 